\title{
Mantle Potential Temperature Estimates and Primary Melt Compositions of the Low-Ti Emeishan Flood Basalt
}

\author{
J. G. Shellnutt* and Thuy T. Pham \\ Department of Earth Science, National Taiwan Normal University, Taipei, Taiwan
}

The Late Permian Emeishan large igneous province (ELIP) is considered to be one of the best examples of a mantle plume derived large igneous province. One of the primary observations that favor a mantle plume regime is the presence of ultramafic volcanic rocks. The picrites suggest primary mantle melts erupted and that mantle potential temperatures $\left(T_{\mathrm{P}}\right)$ of the ELIP were $>200^{\circ} \mathrm{C}$ above ambient mantle conditions. However, the picrites may represent a mixture of liquid and cumulus olivine and pyroxene rather than primary liquids. Consequently, temperature estimates based on the picrite compositions may not be accurate. Here we calculate mantle potential temperature $\left(T_{P}\right)$ estimates and primary liquids compositions using PRIMELT3 for the low-Ti $(\mathrm{Ti} / \mathrm{Y}<500)$ Emeishan basalt as they represent definite liquid compositions. The calculated $T_{\mathrm{P}}$ yield

Edited by:

Scott Andrew Whattam, Indian Institute of Technology

Bhubaneswar, India

Reviewed by:

Georg F. Zellmer,

Massey University, New Zealand David W. Peate

University of lowa, United States

${ }^{*}$ Correspondence:

J. G. Shellnutt

jgshelln@ntnu.edu.tw

Specialty section:

This article was submitted to

Petrology,

a section of the journal

Frontiers in Earth Science

Received: 20 February 2018 Accepted: 14 May 2018

Published: 31 May 2018

Citation:

Shellnutt JG and Pham TT (2018)

Mantle Potential Temperature

Estimates and Primary Melt a range from $\sim 1,400$ to $\sim 1,550^{\circ} \mathrm{C}$, which is consistent with variability across a mantle plume axis. The primary melt compositions of the basalts are mostly picritic. The results of this study indicate that the Emeishan basalt was produced by a high temperature regime and that a few of the ultramafic volcanic rocks may be indicative of primary liquids.

Keywords: mantle plume, Emeishan large igneous province, mantle potential temperatures, primary melt composition, Permian

\section{INTRODUCTION}

Continental flood basalt provinces and oceanic plateaux are the remnants of atypical mantle melting in anorogenic tectonic settings (White and McKenzie, 1989, 1995; Coffin and Eldholm, 1994; Jerram and Widdowson, 2005). The significant volume $\left(>10^{5} \mathrm{~km}^{3}\right)$ of primarily mafic volcanic rocks in flood basalt provinces is thought to be related to anomalous thermal conditions associated with deep mantle (mantle plume) upwelling (Richards et al., 1989; Griffiths and Campbell, 1990; Ernst and Buchan, 2003; Ernst et al., 2005). However, not all flood basalts (continental or oceanic) are attributed to mantle plumes and it is possible that some are derived by decompressional melting of fertile mantle associated with tensional plate stress or lithospheric delamination induced upwelling (Sheth, 1999; Anderson, 2005; Foulger, 2010). The distinction between mantle plume-derived and non-mantle plume-derived may have implications for biological evolution as the five major mass extinctions (Ordovician-Silurian, Late Devonian, Permian-Triassic, Triassic-Jurassic and Cretaceous-Paleogene) are contemporaneous with flood basalt eruptions of which the three youngest are thought to contemporaneous with mantle plume derived flood basalts (Rampino and Stothers, 1988; Wignall, 2001; Courtillot and Renne, 2003; Phipps Morgan et al., 2004; Self et al., 2005; Sobolev et al., 2011; Rampino and Caldeira, 2018). 
There are a number of geochemical, geological, and geophysical criteria used to identify mantle plume-derived continental flood basalt provinces in the geological record (Ernst and Buchan, 2003; Xu et al., 2004; Ernst et al., 2005; Campbell, 2007; Bryan and Ferrari, 2013). However, some criteria, such as uplift and doming of the crust, are more difficult to evaluate than others especially within older or dismembered flood basalt provinces. Therefore, one of the key criteria for identifying a mantle plume-related flood basalt province is estimating the mantle potential temperature $\left(T_{\mathrm{P}}\right)$ required to generate a primary melt of the lava that erupted (Herzberg et al., 2007; Herzberg and Asimow, 2008; Rey, 2015). It is expected that the thermal regime of a mantle plume is $\sim 250^{\circ} \mathrm{C}$ higher than that of the ambient $\left(1,300-1,400^{\circ} \mathrm{C}\right)$ mantle temperature (Farnetani and Richards, 1994; Herzberg and O'Hara, 2002; Herzberg et al., 2007). Ultramafic volcanic rocks are commonly found in the lower volcanic sequences of flood basalt provinces, generated by high degrees of melting under high mantle temperatures, and provide a clear record of the thermal regime (Herzberg and O'Hara, 2002; Kamenetsky et al., 2012). In cases where ultramafic volcanic rocks are unexposed or unidentified, mafic volcanic (basalt) rocks may also be able to help constrain the thermal regime, providing that they have not experienced pyroxene or plagioclase fractionation or were not derived from a volatilerich and/or pyroxenite source (Coltice et al., 2007; Herzberg et al., 2007; Herzberg and Gazel, 2009; Hole, 2015; Whalen et al., 2015; Shellnutt and Hsieh, 2016; Yeh and Shellnutt, 2016).

The Emeishan large igneous province (ELIP) of SW China is considered to be one of the best examples of a mantle plume derived continental flood basalt province (Chung and Jahn, 1995; Chung et al., 1998; He et al., 2003; Xu et al., 2004; Ali et al., 2005; Campbell, 2005; Shellnutt, 2014). The presence of ultramafic volcanic rocks (picrites) and a short (2-3 million years) eruptive duration are the primary evidence for a mantle plume origin of the ELIP (Ali et al., 2005; Shellnutt et al., 2012; Shellnutt, 2014; Zhong et al., 2014). Regional uplift and doming of the crust is suggested but the evidence is debated and, moreover, may not be a priori evidence for a mantle plume-derived large igneous province (c.f. Ukstins Peate and Bryan, 2008; Sun et al., 2010; Wang et al., 2014). The eruptive and mantle potential temperatures of the picrites were estimated using a variety of techniques including REE inversion, whole rock compositions, and melt inclusions (Xu et al., 2001; Zhang et al., 2006; Ali et al., 2010; Hanski et al., 2010; He et al., 2010; Tao et al., 2015). Most of the $T_{\mathrm{P}}$ estimates yield temperatures $>1,530^{\circ} \mathrm{C}$ (up to $1,810^{\circ} \mathrm{C}$ ). However, melt inclusion studies of olivine demonstrate a wide range of compositions suggesting that the picrites may not represent pure liquid compositions but rather a mixture of cumulus minerals and liquid (Kamenetsky et al., 2012; Ren et al., 2017). Consequently, mantle potential temperature estimates $\left(T_{\mathrm{P}}\right)$ and primary liquid compositions based on the whole rock picrite data may not be accurate.

Most Emeishan picrites are porphyritic and can contain up to $30 \%$ phenocrysts, some of which may be antecrysts (Tao et al., 2015). In comparison, most Emeishan basalts are aphyric and more likely to be representative of liquid compositions. Thus, the
Emeishan basalt that has only experienced olivine fractionation is likely to provide robust $T_{\mathrm{P}}$ and primary liquid composition estimates (Herzberg and Asimow, 2015). In this paper we calculate the mantle potential temperatures and the primary liquid compositions of the low- $\mathrm{Ti}(\mathrm{Ti} / \mathrm{Y}<500)$ Emeishan basalt in order to constrain the thermal regime of the ELIP and the range of possible primary liquid compositions. The results can help to elucidate the composition of the primary melts that either erupted or differentiated within the crust and the thermal conditions associated with the ELIP.

\section{BACKGROUND GEOLOGY}

The Middle-Late ( $260 \mathrm{Ma})$ Permian ELIP covers an area of $\sim 0.3 \times 10^{6} \mathrm{~km}^{2}$ along the western margin of the Archean to Paleoproterozoic Yangtze Craton of the South China Block (Ali et al., 2005; Shellnutt, 2014). Correlative dismembered units are found in the Songpan-Ganzi terrane of the Tibetan Plateau and the Phan Si Pan uplift in northern Vietnam (Figure 1). The flood basalts are volumetrically the largest unit but there are minor volumes of ultramafic (picrite) and silicic volcanic rocks (Chung and Jahn, 1995; Hanski et al., 2004; Zhang et al., 2006; Wang et al., 2007; Shellnutt and Jahn, 2010; Xu et al., 2010; Anh et al., 2011; Tran et al., 2015; Usuki et al., 2015). The picrites are restricted to the lower half of the volcanic succession whereas the basalticandesites and silicic volcanic rocks tend to be found in the upper half. The volcanic rocks erupted within a short duration (2-3 Ma) on top of middle Permian limestone or directly on Precambrian cratonic rocks of the Yangtze Block (He et al., 2003; Zheng et al., 2010; Shellnutt et al., 2012; Zhong et al., 2014). The plutonic units consist of ferroan alkalic granites (A-type), ore-bearing layered mafic-ultramafic intrusions and mafic dykes (Shellnutt and Zhou, 2007; Shellnutt et al., 2008; Pang et al., 2010; Li et al., 2015).

The chemical subdivision of the Emeishan flood basalts into low- and high-Ti groups is primarily based on the Ti/Y (Ti/Y $>500=$ high-Ti; $\mathrm{Ti} / \mathrm{Y}<500=$ low-Ti) ratio and bulk $\mathrm{TiO}_{2}$ wt\% $\left(\mathrm{TiO}_{2}>2.5=\right.$ high-Ti; $\mathrm{TiO}_{2}<2.5=$ low-Ti $)$ content. Additional subgroupings are identified using the $\mathrm{Sm} / \mathrm{Yb}$ ratio, $\mathrm{Mg \# ,} \varepsilon_{\mathrm{Nd}}(t)$, and the fractionating mineral assemblage (Xu et al., 2001; Xiao et al., 2004). The picrites can be subdivided on the basis of the Ti/Y ratio but also using chondrite normalized rare earth element ratios (c.f. Kamenetsky et al., 2012). The basalt classification scheme is rather cumbersome as there are at least 5 types of Emeishan flood basalt (low-Ti 1, low-Ti 2, high-Ti 1, high-Ti 2, high-Ti 3). If a large database is compiled the subdivision of the basalts and picrites into two broad groups is a little misleading as it is clear there is compositional continuum from low-Ti to high-Ti varieties (Hao et al., 2004; Shellnutt and Jahn, 2011; Kamenetsky et al., 2012). Nevertheless, it can be stated that there are mafic and ultramafic volcanic rocks with lower $(<2$ wt $\%$ ) and higher (> $2.5 \mathrm{wt} \%) \mathrm{TiO}_{2}$.

The emplacement of the ELIP is coeval with the endGuadalupian mass extinction and may have contributed to the decline of biota (Bond and Wignall, 2014; Rampino and Caldeira, 2018). Based on seismic studies, the ELIP is structurally divided into three roughly concentric zones 


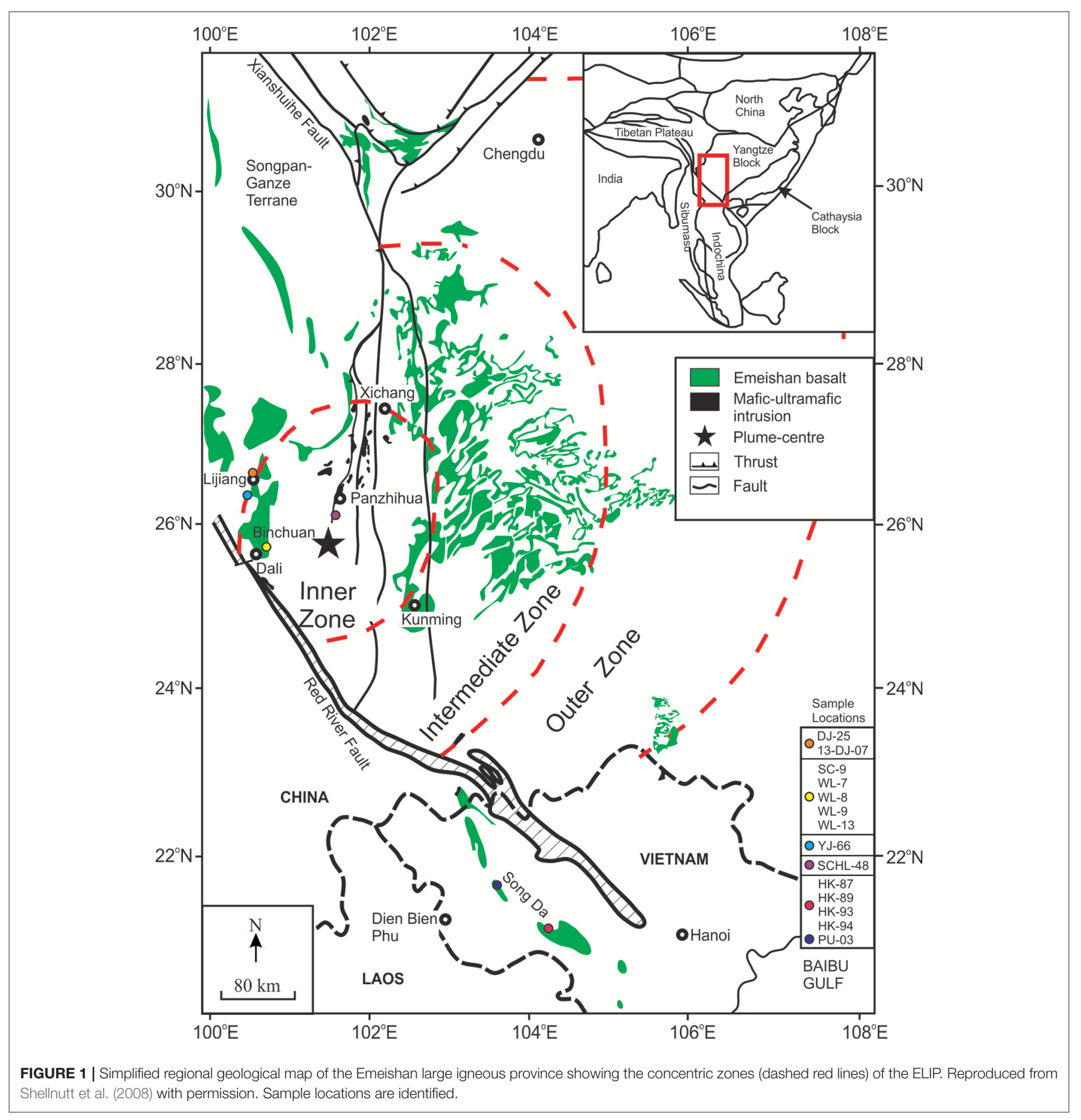

(inner, intermediate and outer), which correspond to crustal thickness estimates with the inner zone having the thickest crust that progressively thins to outer zone (Xu et al., 2004). There is some evidence to suggest the Yangtze Craton experienced uplift and doming of the crust prior to the eruption of the flood basalts, however it is debated ( $\mathrm{He}$ et al., 2003; Ukstins Peate and Bryan, 2008, 2009; Sun et al., 2010)

\section{METHOD}

For this paper we compiled a database using GEOROC (http:// georoc.mpch-mainz.gwdg.de/georoc/) of over 450 whole rock analyses of Emeishan basalt. The initial selection criteria

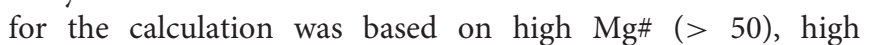
$\mathrm{MgO}$ (>6 wt\%), and high bulk $\mathrm{CaO}$ ( $>11$ wt\%) because rocks with lower values likely experienced clinopyroxene \pm 
plagioclase fractionation and are unsuitable for the calculation. Primary melt compositions and mantle potential temperature estimates $\left(T_{\mathrm{P}}\right)$ were calculated for Emeishan basalt using PRIMELT3 (Herzberg and Asimow, 2015). PRIMELT3 allows the user to adjust source parameters (e.g., relative oxidation state, FeOt, and $\mathrm{MgO}$ content) and pressure conditions that may better reflect the conditions of melt formation. Previous $T_{\mathrm{P}}$ calculations of the Emeishan ultramafic volcanic rocks used PRIMELT2 (Ali et al., 2010; He et al., 2010), however there are significant improvements in PRIMELT3 that include: correcting melt fractions, identifying the residuum mineralogy, and improved uncertainty in the thermal estimates (Herzberg and Asimow, 2015). The estimated mantle potential temperatures are considered to be accurate to $\pm 42^{\circ} \mathrm{C}$ (Herzberg and Asimow, 2015).

The bulk FeOt content of off-craton peridotite is 8.14 \pm 0.9 wt\% (Herzberg, 1993; Herzberg and O'Hara, 2002). The consequences of melting of an Fe-rich $(\mathrm{FeOt}=9.0$ wt\%) peridotite are discussed by Herzberg and O'Hara (2002) in detail but the net result is that the primary liquids will be elevated by $\sim 0.9 \mathrm{wt} \%$ FeOt at most pressures. The default setting in PRIMELT3 for bulk mantle FeOt is $8.02 \mathrm{wt} \%$ although it is suggested that varying the FeOt content may be useful in reproducing melt fractions from Fe-rich and Fe-poor peridotite (Herzberg and Asimow, 2015). We used the lowest possible mantle FeOt (8.02$8.41 \mathrm{wt} \%)$ content that yields internally consistent results (e.g., no $\mathrm{Fe} / \mathrm{Mg}$ and $\mathrm{Na} / \mathrm{Si}$ errors) for each sample and dismiss results that indicate the melts are generated from a volatile-rich mantle source or from pyroxenite mantle source (Table S1).

The relative oxidation state of the Emeishan basalt was calculated using the method of Kress and Carmichael (1991) and produced a $\triangle F M Q$ (fayalite-magnetite-quartz) range from -1 to +1 with an average of +0.1 (Shellnutt and Iizuka, 2012). Moreover, the $\mathrm{V} / \mathrm{Ga}$ ratios range from $\sim 8$ to $\sim 27$, which corresponds to a relative oxidation stage ranging from $\triangle \mathrm{FMQ}-2$ to +1 (Mallmann and O'Neill, 2009). Consequently, each sample was calculated using an $\mathrm{Fe}_{2} \mathrm{O}_{3} / \mathrm{TiO}_{2}$ ratio of 0.5 (reducing) and 1.0 (oxidizing) that reflects the range of relative oxidation state of the basalt (Table S1). The models were calculated at surface pressure $(1 \mathrm{~atm})$ and without water $\left(\mathrm{H}_{2} \mathrm{O}=0\right)$.

\section{RESULTS}

A total of 14 samples were identified that produced meaningful results (Table S1). All samples classify as low-Ti Emeishan basalt $\left(\mathrm{TiO}_{2} \leq 2.2 \mathrm{wt} \% ; \mathrm{Ti} / \mathrm{Y}<500\right)$ and have bulk $\mathrm{CaO}>11.3$ wt\%. Two samples (SC-9, HK-89) have low Mg\# ( 50) and $\mathrm{Ni}<100 \mathrm{ppm}$ which suggests they experienced more olivine removal than other samples as they were able to produce meaningful results (Table S1). The high-Ti basalt with high $\mathrm{Mg \# ,} \mathrm{MgO}$ and $\mathrm{CaO}$ did not yield internally consistent results, which led to calculation errors ( $\mathrm{Fe} / \mathrm{Mg}$ error, $\mathrm{Na} / \mathrm{Si}$ error) and the necessity of a volatile source or indicated pyroxene fractionation. It is thought that volatile compounds (e.g., $\mathrm{CO}_{2}$, $\mathrm{H}_{2} \mathrm{O}$ ) may play a larger role in the genesis of the "highTi" basalt or that they are derived from a pyroxenite source (Xu et al., 2001; Xiao et al., 2004; Zhou et al., 2008; Shellnutt and Jahn, 2011; Kamenetsky et al., 2012).

The melt compositions under reducing conditions $\left(\mathrm{Fe}_{2} \mathrm{O}_{3} / \mathrm{TiO}_{2}=0.5\right)$ are not significantly different than the melts generated under oxidizing conditions $\left(\mathrm{Fe}_{2} \mathrm{O}_{3} / \mathrm{TiO}_{2}=\right.$ 1.0). The calculations indicate the primary melts are low- $\mathrm{Ti}$ $\left(\mathrm{TiO}_{2}<2 \mathrm{wt} \%\right)$ and mostly picritic $(\mathrm{MgO}=13.3 \mathrm{wt} \%$ to 20.0 wt\%) with four samples (HK-89, WL-13, SC-9, DJ-25) that are komatiitic/meimechitic (Figure 2). There are differences between calculated temperatures of the two oxidation state models. The estimated eruptive temperatures are consistently lower in the oxidizing $\left(1,315-1,410^{\circ} \mathrm{C}\right)$ models compared to the reducing $\left(1,330-1,435^{\circ} \mathrm{C}\right)$ models with temperature differences as little as $\sim 15^{\circ} \mathrm{C}$ to as high as $\sim 40^{\circ} \mathrm{C}$. The estimated $T_{\mathrm{P}}$ are also lower $\left(\right.$ mean $=1470 \pm 22^{\circ} \mathrm{C}$ ) in the oxidizing $\left(1,390-1,530^{\circ} \mathrm{C}\right)$ models in comparison to the reducing $(1,410-$ $1,560^{\circ} \mathrm{C}$ ) models (mean $=1505 \pm 22^{\circ} \mathrm{C}$ ), but the difference between the two models is larger $\left(\sim 20\right.$ to $\left.\sim 65^{\circ} \mathrm{C}\right)$ than the difference between the eruptive temperatures (Figure 3). The estimated uncertainty of the eruptive temperatures is $\pm 31^{\circ} \mathrm{C}$ indicated that the oxidizing and reducing estimates are broadly within uncertainty (Herzberg et al., 2007). The same is true for the oxidizing and reducing mantle potential temperatures estimates as they are mostly with the calculation uncertainty $\left( \pm 42^{\circ} \mathrm{C}\right)$. The estimated pressure of melting, with an uncertainty of $\pm 0.3 \mathrm{GPa}$, using the maximum primary melt $\mathrm{MgO}$ content ranges from $\sim 2.4 \mathrm{GPa}(\mathrm{HK}-94)$ to $\sim 4.8 \mathrm{GPa}$ (SC-9) and corresponds to a depth range of $\sim 70$ to $\sim 145 \mathrm{~km}$ (Herzberg and Asimow, 2015).

\section{DISCUSSION}

\section{Thermal and Compositional Estimates of the Emeishan Primary Magmas}

The crystallization temperatures based on the primary melt compositions of the low-Ti basalt in this study are between 1,300 and $1,450^{\circ} \mathrm{C}$ (oxidizing models $=1,315-1,410^{\circ} \mathrm{C}$; reducing models $=1,330-1,435^{\circ} \mathrm{C}$ ) and similar to the estimates using Al-in-olivine for komatiites and basalts from Gorgona, Baffin Island, SE Greenland and Madagascar but much higher than estimates $\left(<1,300^{\circ} \mathrm{C}\right)$ for mid-ocean ridge basalt (Coogan et al., 2014; Shellnutt and Hsieh, 2016). The Al-in-olivine thermometer method produced a range of crystallization temperatures from $1,188 \pm 56^{\circ} \mathrm{C}$ to $1,440 \pm 63^{\circ} \mathrm{C}$ (low- $\mathrm{Ti}$ picrites $=1249 \pm 58^{\circ} \mathrm{C}-1356 \pm 61^{\circ} \mathrm{C}$ ) for all compositions of the ELIP picrites (Xu and Liu, 2016). The lower temperature estimates are from olivine which have lower $F o$-values $(<86)$, lower $\mathrm{Al}_{2} \mathrm{O}_{3} \quad(<0.05 \mathrm{wt} \%)$ and lower $\mathrm{NiO}(<0.32$ wt $\%)$ contents and likely indicate a cooling trend within the system (Figure 3). Xu and Liu (2016) suggest that the higher crystallization temperatures of the ELIP picrites can only be reconciled within the context of a mantle plume model. 


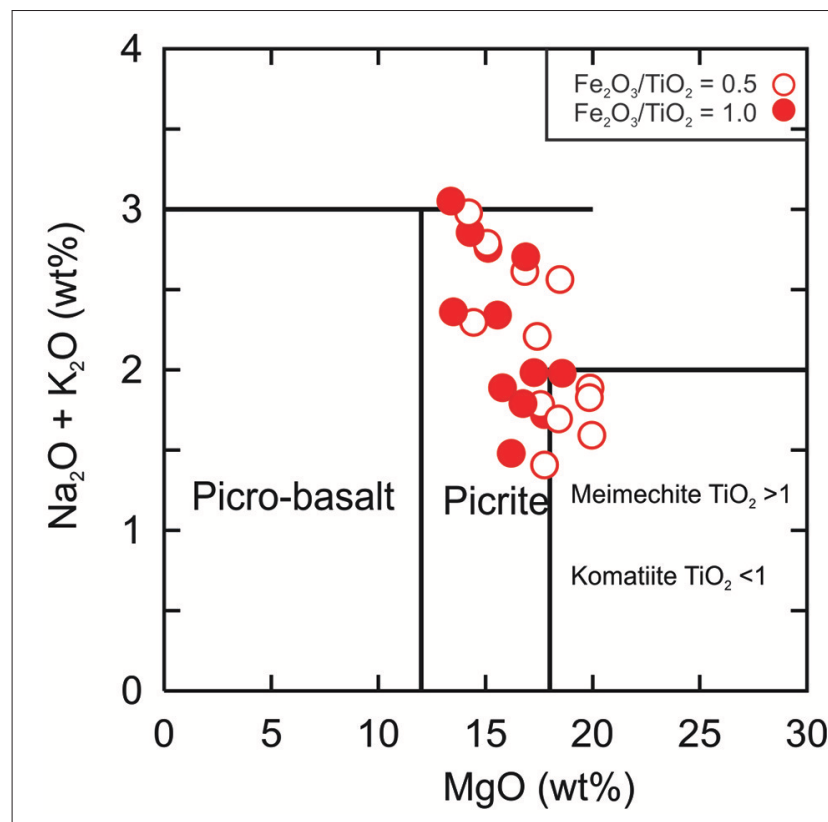

FIGURE 2 | Classification of the primary liquid composition calculated in this study using the scheme of Le Bas (2000). Data compiled from Song et al. (2001); Xiao et al. (2004); Zhang et al. (2006); Wang et al. (2007); Zi et al. (2008), and Arguin et al. (2016).

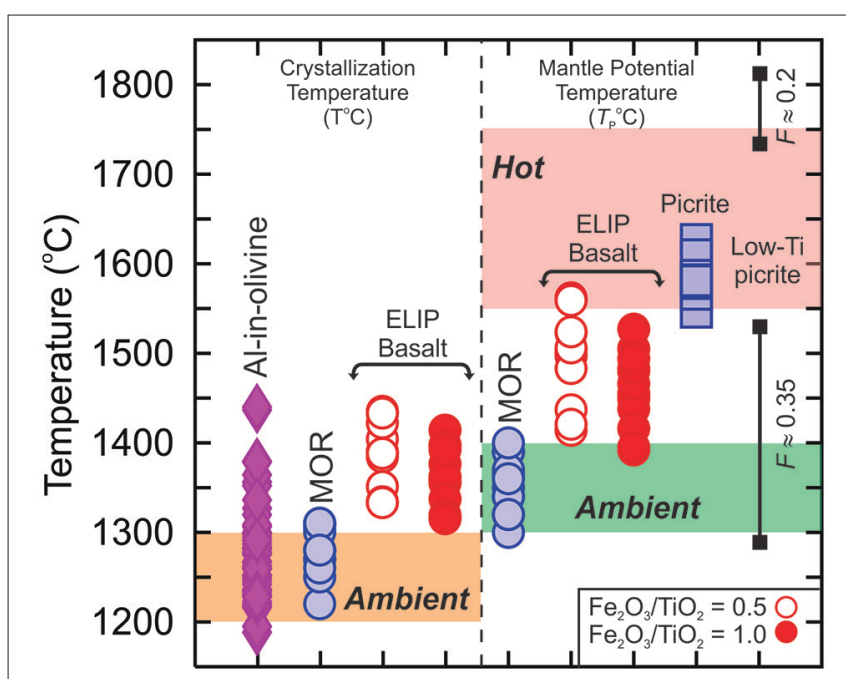

FIGURE 3 | Comparison of crystallization $\left(\mathrm{T}^{\circ} \mathrm{C}\right)$ and mantle potential temperature $\left(T_{\mathrm{P}}^{\circ} \mathrm{C}\right)$ estimates of the ELIP. The results of this study are shown as red circles and white circles with red trim (ELIP basalt). The Al-in-olivine crystallization temperature estimates (diamonds) are for intermediate and low-Ti Emeishan picrite inclusions (Xu and Liu, 2016). The mantle potential temperature estimates of picrite $T_{P}$ (squares) are estimated using PRIMELT2 (He et al., 2010). The olivine-liquid $T_{P}$ (vertical black lines) estimates for low-Ti Emeishan picrite using melt fractions of $(F)$ of $\approx 0.35$ and $\approx 0.2$ (Tao et al., 2015). Crystallization and mantle potential temperature estimates (blue circles) of mid-ocean ridge (MOR) basalt are also shown (Shellnutt and Hsieh, 2016).

Mantle potential temperature estimates using olivine-liquid equilibration estimates of the "low-Ti" picrites range from 1,536 to $1,296^{\circ} \mathrm{C}$ but, depending on the melt fraction used, may be as high as $1,740-1,810^{\circ} \mathrm{C}$ (Figure 3; Tao et al., 2015). Our $T_{\mathrm{P}}$ estimates $\left(\sim 1,400\right.$ to $\left.\sim 1,550^{\circ} \mathrm{C}\right)$ are generally higher but broadly match the results using a melt fraction $(F)$ of $\approx 0.35$. However, we think the maximum temperature estimates based on olivineliquid equilibration and $F$-value of $\approx 0.2$ are too high $(1,740-$ $1,810^{\circ} \mathrm{C}$ ) as the suggested temperature range overlaps with and possibly exceeds estimates for Archean thermal regimes (Lee et al., 2010). It is possible that the differences between the $T_{\mathrm{P}}$ estimates using PRIMELT3 and olivine-liquid equilibration may be due to the origin of the olivine within the picrite (i.e., antecryst, xenocryst). Although Xu and Liu (2016) did not report mantle potential temperature estimates based on their results, Matthews et al. (2016) using the same method for olivine from Iceland volcanic rocks suggests the highest observed crystallization temperature $\left(1399 \pm 20^{\circ} \mathrm{C}\right)$ constrains the mantle potential temperature to $1,480_{-30}^{+37 \circ} \mathrm{C}$. This suggests the highest crystallization temperature estimate $\left(1,440 \pm 63^{\circ} \mathrm{C}\right)$ of Xu and Liu (2016) probably corresponds to a mantle potential temperature $>1,500^{\circ} \mathrm{C}$ and thus could be representative of hot thermal regime.

A comparison of the calculated primary melt compositions of this study with those derived from melt inclusions of the lowTi picrites show that, in spite of the differences in the applied methods, the results are broadly similar (Figure 4). The primary melt composition estimates from the Dali picrite inclusions have considerable variation but those from the Binchuan picrites, specifically the estimates of Ren et al. (2017) for sample EM43, are closer to the estimates of this study. Furthermore, it is clear that most low-Ti picrites are different from the primary melt compositions, supporting the notion that they are not pure liquid compositions. The group of picrites with low $\mathrm{SiO}_{2}(<45 \mathrm{wt} \%)$ and high $\mathrm{Al}_{2} \mathrm{O}_{3}$ (9-12 wt\%) were collected to the west of Xichang near Muli are described as having porphyritic textures with phenocrysts of clinopyroxene and plagioclase indicating they may represent mixtures of cumulate clinopyroxene and plagioclase and lava (Li et al., 2010). There are a few picrites (HK-5, HK-92; YJ-66; EM-83; PU-03) that overlap in all major elements indicating they may be closer to primary liquid compositions. In fact samples YJ-66 and PU-03 yield $T_{\mathrm{P}}$ estimates of $1,500-1,530^{\circ} \mathrm{C}\left(\mathrm{Fe}_{2} \mathrm{O}_{3} / \mathrm{TiO}_{2}=1.0\right)$, and $1,536-1,547^{\circ} \mathrm{C}\left(\mathrm{Fe}_{2} \mathrm{O}_{3} / \mathrm{TiO}_{2}=0.5\right)$ which are consistent with the high $T_{\mathrm{P}}$ estimates from the basalt (Table $\mathrm{S} 1$ ).

\section{Mantle Plume Structure of the Emeishan Large Igneous Province}

The mantle potential temperature estimates of the oxidizing and reducing models range from $\sim 1,400$ to $\sim 1,550^{\circ} \mathrm{C}$. The lower end temperatures are consistent with ambient mantle conditions $\left(1,300-1,400^{\circ} \mathrm{C}\right)$ whereas the higher end temperatures are anomalously $\left(\sim 1,550^{\circ} \mathrm{C}\right)$ high (Green and Falloon, 2005; Campbell, 2007; Herzberg et al., 2007). The relatively large temperature range $\left(\sim 150^{\circ} \mathrm{C}\right)$ is not that unusual as other large igneous provinces (Deccan, East Africa, North Atlantic, Caribbean, Central Atlantic Magmatic Province) and oceanic islands (Hawaii, Cook) have a similar range (Herzberg and Asimow, 2008; Rooney et al., 2012; Hole, 2015; 

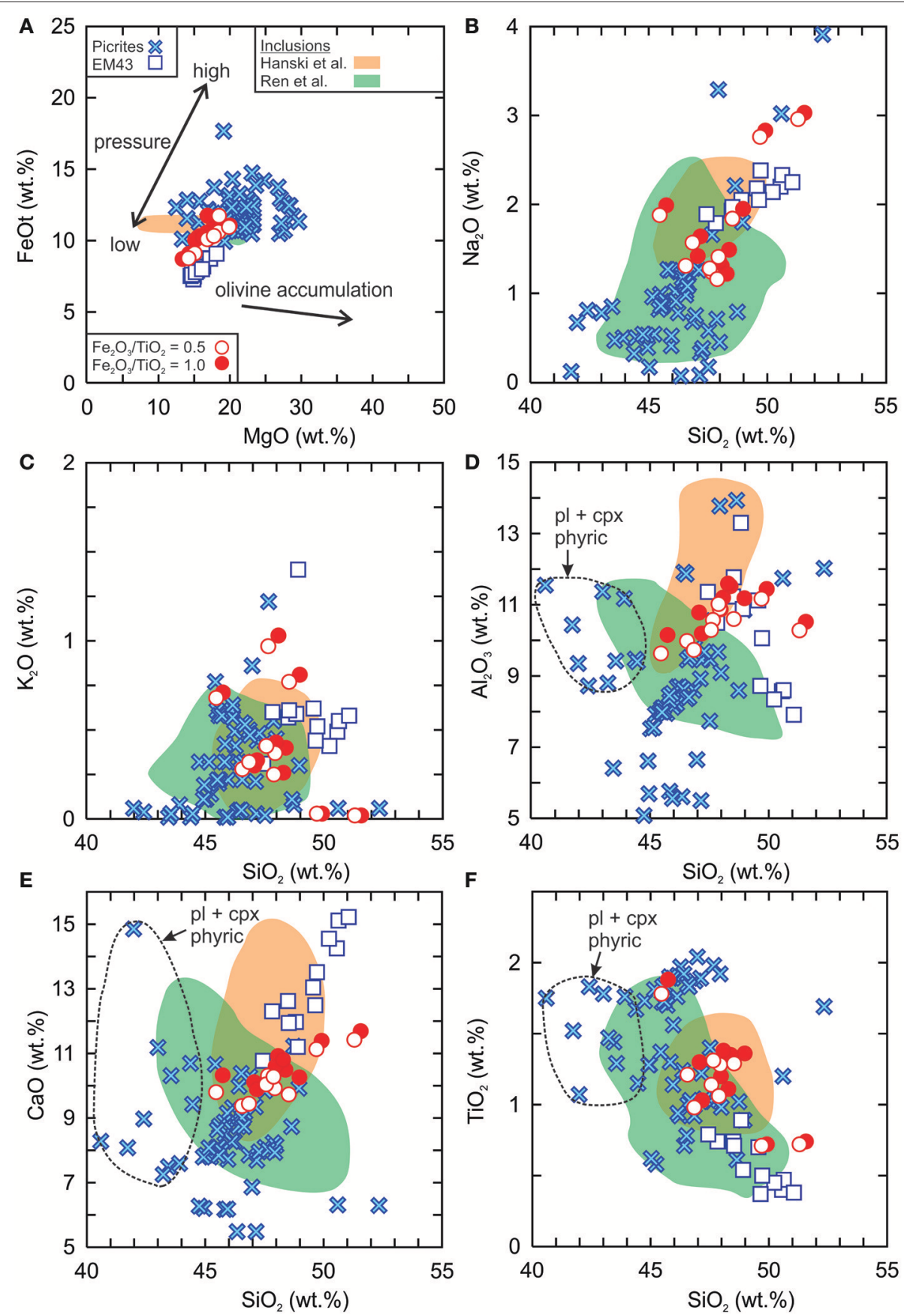

FIGURE 4 | Comparison of the calculated primary melt compositions of the low-Ti Emeishan basalt (circles) with the whole rock compositions of the low-Ti picrites (blue crosses), the primary melt composition derived from inclusions of sample EM43 (squares), and inclusions from the Dali picrites (green field = Ren et al., 2017; orange field = Hanski et al., 2010). (A) FeOt wt.\% vs. $\mathrm{MgO}$ wt.\%, (B) $\mathrm{Na}_{2} \mathrm{O}$ wt.\% vs. $\mathrm{SiO}_{2}$ wt.\%, (C) $\mathrm{K}_{2} \mathrm{O}$ wt. \% vs. $\mathrm{SiO}_{2}$ wt. \%, (D) Al $\mathrm{O}_{3}$ wt.\% vs. $\mathrm{SiO}_{2}$ wt.\%, (E) $\mathrm{CaO}$ wt \% vs. $\mathrm{SiO}_{2}$ wt.\%, and (F) $\mathrm{TiO}_{2}$ wt.\% vs. $\mathrm{SiO}_{2}$ wt.\%. The olivine accumulation and relative pressure arrows are taken from Arndt (2003). The low-Ti picrite data are from Kamenetsky et al. (2012); the EM43 (low-Ti picrite) and Dali picrite inclusions are from Ren et al. (2017). The picrites reported from Muli are plagioclase (pl) and clinopyroxene (cpx) phyric (Li et al., 2010). All data are normalized to 100\%.

Shellnutt et al., 2018). In many cases the temperature variability is attributed to the thermal structure of a mantle plume, where hot primary melts are derived from the plume axis and cooler primary melts are derived from the periphery (Herzberg and Gazel, 2009; Hole and Millet, 2016). Therefore, we suggest that the high $T_{\mathrm{P}}$ estimates of the basalts are indicative of an anomalously hot thermal regime for the ELIP and consistent with the expected conditions associated with a mantle plume (Campbell, 2007). The rocks that yield lower $T_{\mathrm{P}}$ estimates (HK93, HK94, SCHL-48) may either be due to melts derived from the 
peripheral regions of the plume axis or melt extraction during the waning stages of volcanism. Rare earth element ratios for the three samples that produced the lowest $T_{\mathrm{P}}$ estimates $(1,410-$ $1,440^{\circ} \mathrm{C}$ ) have the lowest chondrite normalized $\mathrm{La} / \mathrm{Yb}$ ratios $(1.7-$ 1.8), although sample SCHL-48 has high ratio (5.1), and low $\mathrm{Dy} / \mathrm{Yb}$ ratios (1.6-2.1) which favor a spinel peridotite source. In comparison, the samples that produced high $T_{\mathrm{P}}$ estimates $\left(1,480-1,560^{\circ} \mathrm{C}\right)$ have $\mathrm{La} / \mathrm{Yb}_{\mathrm{N}}$ ratios from 3.7 to $5.1, \mathrm{Dy} / \mathrm{Yb}$ ratios of 1.9-2.4 which indicates the possibility of residual garnet in the source and thus originated from greater depth (Davidson et al., 2013).

The basalts in this study are principally from the western portion (Binchuan, Lijiang, Panzhihua) or the displaced western portion (Song Da) of the ELIP, therefore a complete spatialthermal characterization cannot be fully developed. However, the basalts examined from different areas (Heishitou, Yanghe, Longlin, Xilin, Bama, Baise, Tianyang) of the eastern ELIP (Sichuan, Guizhou, Guangxi) are mostly of the "high-Ti" variety, but even those that are "low-Ti" typically have characteristics $(\mathrm{CaO} \leq 10 \mathrm{wt} \% ; \mathrm{MgO}<6 \mathrm{wt} \%)$ indicative of clinopyroxene $( \pm$ plagioclase) fractionation (Qi and Zhou, 2008; Lai et al., 2012; Li et al., 2017; Liu et al., 2017).

The hypothetical ELIP plume-center, based on dyke orientation, is suggested to be located south-southwest of Panzhihua $(\sim 60 \mathrm{~km})$ near Yongren County (Yunnan) (Li et al., 2015). The radial distribution of dykes is compelling evidence that favors a plume-center in southern Sichuan-northern Yunnan, but the western margin of the ELIP is highly tectonized and dismembered (Song et al., 2006; Zi et al., 2010; Usuki et al., 2015; Li et al., 2016). For example the Song Da region of Northern Vietnam was displaced $\sim 600 \mathrm{~km}$ to the SE along the Ailaoshan-Red River fault system during the Oligocene (Chung et al., 1997). Therefore, the original areal distribution of basalts in the west prior to accretion and deformation of the Songpan-Ganzi terrane is poorly constrained (Weislogel et al., 2010). However, the fact that the basalts that successfully yielded primary melt compositions are exclusively from the western region (inner zone) of the ELIP is unlikely to be random. The implication is that the low-Ti Emeishan basalt located in the west are closer to primary melt compositions than those located in the east. It is possible that the "western" basalt erupted closer to the hypothetical plume-center.

The eastern low-Ti Emeishan basalt may have erupted further from the plume-center and thus had more time to fractionate other silicate minerals (i.e., clinopyroxene and plagioclase) during their transit through the crust or that they were derived from a pyroxenitic source. The pressure estimates based on $\mathrm{MgO}$ content of the primary melt compositions from the reducing models $\left(\mathrm{Fe}_{2} \mathrm{O}_{3} / \mathrm{TiO}_{2}=0.5\right)$ ranges from $\sim 2.4 \mathrm{GPa}$ to $\sim 4.8$ $\mathrm{GPa}$ and covers an equivalent depth range of $\sim 70 \mathrm{~km}(\sim 70$ to $\sim 145 \mathrm{~km}$ ). The high pressure melts, which have the highest $T_{\mathrm{P}}$, correspond to a region beneath the lithosphere of the Yangtze Craton that has high seismic velocity $(V \mathrm{p})$ zone and is interpreted to be solid residue after melt extraction of the Emeishan mantle plume (Liu et al., 2001; Xu et al., 2004). In contrast, the low pressure melts, which have the lowest $T_{\mathrm{P}}$, correspond to a high velocity lower crust region beneath inner zone of the ELIP, which is interpreted to be a region of magmatic underplating (Xu et al., 2004; Chen et al., 2015). It is possible that the region of underplating served as a zone where primary melts initially differentiated before forming layered mafic-ultramafic intrusions within the middle-upper crust (Hou et al., 2012; Zhang et al., 2012; Bai et al., 2014; Shellnutt and Wang, 2014). The high $T_{\mathrm{P}}$ estimates, melt extraction pressure estimates, geographic location of the picrites and basalt that yield high $T_{\mathrm{P}}$ estimates, and the spatial distribution of the basalt, all suggest that the structure of the ELIP was the likely consequence of a mantle plume.

\section{CONCLUSIONS}

The primary melt compositions of the low-Ti Emeishan basalts are chemically similar to picritic melts and broadly similar to primary melt compositions determined from melt inclusions of the low-Ti Emeishan picrites. A few of the Emeishan picrites overlap with the primary melt compositions, indicating that some may be representative of primary liquids. The highest $T_{\mathrm{P}}$ estimates yielded temperatures $>1,550^{\circ} \mathrm{C}$, indicating that the thermal regime of ELIP reached temperatures $>250^{\circ} \mathrm{C}$ above ambient mantle conditions, consistent with the expected thermal regime of a mantle plume.

\section{AUTHOR CONTRIBUTIONS}

JS designed the project, calculated the models, interpreted the results and wrote the paper. TP collected and processed the samples. All authors contributed to the discussion of results.

\section{FUNDING}

This study was supported by the Ministry of Science and Technology (Taiwan) grant (106-2116-M-003-007) to JS. TP was supported by the Society of Economic Geologists Student grant program (2015).

\section{ACKNOWLEDGMENTS}

We thank George Zellmer and David Peate for their insightful comments that improved the manuscript and editorial comments by Scott Whattam.

\section{SUPPLEMENTARY MATERIAL}

The Supplementary Material for this article can be found online at: https://www.frontiersin.org/articles/10.3389/feart. 2018.00067/full\#supplementary-material 


\section{REFERENCES}

Ali, J. R., Fitton, J. G., and Herzberg, C. (2010). Emeishan large igneous province (SW China) and the mantle-plume up-doming hypothesis. J. Geol. Soc. Lond. 167, 953-959. doi: 10.1144/0016-76492009-129

Ali, J. R., Thompson, G. M., Zhou, M.-F., and Song, X. Y. (2005). Emeishan large igneous province, SW China. Lithos 79, 475-489. doi: 10.1016/j.lithos.2004.09.013

Anderson, D. L. (2005). Large igneous provinces, delamination, and fertile mantle. Elements 1, 271-275. doi: 10.2113/gselements.1.5.271

Anh, T. V., Pang, K.-N., Chung, S.-L., Lin, H.-M., Hoa, T. T., Anh, T. T., et al. (2011). The Song Da magmatic suite revisited: a petrologic, geochemical and $\mathrm{Sr}-\mathrm{Nd}$ isotopic study on picrites, flood basalts and silicic volcanic rocks. J. Asian Earth Sci. 42, 1341-1355. doi: 10.1016/j.jseaes.2011. 07.020

Arguin, J.-P., Pagé, P., Barnes, S.-J., Yu, S.-Y., and Song, X.-Y. (2016). The effect of chromite crystallization on the distribution of osmium, iridium, ruthenium and rhodium in picritic magmas: an example from the Emeishan large igneous province, southwestern China. J. Petrol. 57, 1019-1048. doi: 10.1093/petrology/egw033

Arndt, N. (2003). Komatiites, kimberlites, and boninites. J. Geophys. Res. 108, 2293. doi: 10.1029/2002JB002157

Bai, Z.-J., Zhong, H., Li, C., Zhu, W.-G., He, D.-F., and Qi, L. (2014). Contrasting parental magma compositions for the Hongge and Panzhihua magmatic Fe-TiV oxide deposits, Emeishan large igneous province, SW China. Econ. Geol. 109, 1763-1785. doi: 10.2113/econgeo.109.6.1763

Bond, D. P. G., and Wignall, P. B. (2014). "Large igneous provinces and mass extinction: an update," in Volcanism, Impacts, and Mass Extinctions: Causes and Effects, eds G. Keller and A. C. Kerr (Boulder, CO: Geological Society of America), 29-55.

Bryan, S. E., and Ferrari, L. (2013). Large igneous provinces and silicic large igneous provinces: progress in our understanding over the last 25 years. Geol. Soc. Am. Bull. 125, 1053-1075. doi: 10.1130/B30820.1

Campbell, I. H. (2005). Large igneous provinces and the mantle plume hypothesis. Elements 1, 265-269. doi: 10.2113/gselements.1.5.265

Campbell, I. H. (2007). Testing the plume theory. Chem. Geol. 241, 153-176. doi: 10.1016/j.chemgeo.2007.01.024

Chen, Y., Xu, Y., Xu, T., Si, S., Liang, X., Tian, X., et al. (2015). Magmatic underplating and crustal growth in the Emeishan large igneous province, SW China, revealed by a passive seismic experiment. Earth Planet. Sci. Lett. 432, 103-114. doi: 10.1016/j.epsl.2015.09.048

Chung, S.-L., and Jahn, B.-M. (1995). Plume-lithosphere interaction in generation of the Emeishan flood basalts at the Permian-Triassic boundary. Geology 23, 889-892.

Chung, S.-L., Jahn, B.-M., Genyao, W., Lo, C. H., and Bolin, C. (1998). "The Emeishan flood basalt in SW China: a mantle plume initiation model and its connection with continental breakup and mass extinction at the PermianTriassic boundary," in Mantle Dynamics and Plate Interactions in East Asia, eds M. F. J. Flower, S.-L. Chung, C. H., Lo, and T. Y. Lee (Washington, DC: American Geophysical Union), 47-58.

Chung, S.-L., Lee, T.-Y., Lo, C.-H., Wang, P.-L., Chen, C.-Y., Yem, N. T., et al. (1997). Intraplate extension prior to continental extrusion along the Ailao Shan-Red River shear zone. Geology 25, 311-314.

Coffin, M. F., and Eldholm, O. (1994). Large igneous provinces: crustal structure, dimensions and external consequences. Rev. Geophys. 32, 1-36. doi: 10.1029/93RG02508

Coltice, N., Phillips, B. R., Bertrand, H., and Ricard, Y. (2007). Global warming of the mantle at the origin of flood basalts over supercontinents. Geology 35, 391-394. doi: 10.1130/G23240A.1

Coogan, L. A., Saunders, A. D., and Wilson, R. N. (2014). Aluminumin-olivine thermometry of primitive basalts: evidence of an anomalously hot mantle source for large igneous provinces. Chem. Geol. 368, 1-10. doi: 10.1016/j.chemgeo.2014.01.004

Courtillot, V. E., and Renne, P. R. (2003). On the ages of flood basalt events. C. $R$. Geosci. 335, 113-140. doi: 10.1016/S1631-0713(03)00006-3

Davidson, J., Turner, S., and Pank, T. (2013). Dy/Dy*: variations arising from mantle sources and petrogenetic processes. J. Petrol. 54, 525-537. doi: 10.1093/petrology/egs076
Ernst, R. E., and Buchan, K. L. (2003). Recognizing mantle plumes in the geological record. Annu. Rev. Earth Planet. Sci. 31, 469-523. doi: 10.1146/annurev.earth.31.100901.145500

Ernst, R. E., Buchan, K. L., and Campbell, I. H. (2005). Frontiers in large igneous province research. Lithos 79, 271-297. doi: 10.1016/j.lithos.2004.09.004

Farnetani, C. G., and Richards, M. A. (1994). Numerical investigations of the mantle plume initiation model for flood basalt events. J. Geophys. Res. 99, 13813-13833. doi: 10.1029/94JB00649

Foulger, G. R. (2010). Plates vs Plumes: A Geological Controversy. Chichester: Wiley-Blackwell.

Green, D. H., and Falloon, T. J. (2005). "Primary magmas at mid-ocean ridges, 'hotspots,' and other intraplate settings: constraints on mantle potential temperature," in Plates, Plumes, and Paradigms, eds G. R. Foulger, J. H. Natland, D. C. Presnall, and D. L. Anderson (Boulder, CO: Geological Society of America), 217-247.

Griffiths, R. W., and Campbell, I. H. (1990). Stirring and structure in mantle starting plumes. Earth Planet. Sci. Lett. 99, 66-78. doi: 10.1016/0012-821X(90)90071-5

Hanski, E., Kamenetsky, V. S., Luo, Z.-Y., Xu, Y.-G., and Kuzmin, D. V. (2010). Primitive magmas in the Emeishan large igneous province, southwestern China and northern Vietnam. Lithos 119, 75-90. doi: 10.1016/j.lithos.2010.04.008

Hanski, E., Walker, R. J., Huhma, H., Polyakov, G. V., Balykin, P. A., Hoa, T. T., et al. (2004). Origin of the Permian-Triassic komatiites, northwestern Vietnam. Contrib. Mineral. Petr. 147, 453-469. doi: 10.1007/s00410-004-0567-1

Hao, Y., Zhang, Z., Wang, F., and Mahoney, J. J. (2004). Petrogenesis of high-Ti and low-Ti basalts from the Emeishan large igneous province. Geol. Rev. 50, 587-592. doi: 10.1016/j.oregeorev.2011.07.005

He, B., Xu, Y.-G., Chung, S.-L., Xiao, L., and Wang, Y. (2003). Sedimentary evidence for a rapid, kilometer-scale crustal doming prior to the eruption of the Emeishan flood basalts. Earth Planet. Sci. Lett. 213, 391-405. doi: 10.1016/S0012-821X(03)00323-6

He, Q., Xiao, L., Balta, B., Gao, R., and Chen, J. (2010). Variety and complexity of the Late-Permian Emeishan basalts: reappraisal of plume-lithosphere interaction processes. Lithos 119, 91-107. doi: 10.1016/j.lithos.2010.07.020

Herzberg, C. (1993). Lithosphere peridotites of the Kaapvaal craton. Earth Planet. Sci. Lett. 120, 13-29. doi: 10.1016/0012-821X(93)90020-A

Herzberg, C., and Asimow, P. D. (2008). Petrology of some oceanic islands basalts: PRIMELT2.XLS software for primary magma calculation. Geochem. Geophy. Geosy. 9:Q09001. doi: 10.1029/2008GC002057

Herzberg, C., and Asimow, P. D. (2015). PRIMELT3 MEGA.XLSM software for primary magma calculation: peridotite primary magma $\mathrm{MgO}$ contents from the liquidus to the solidus. Geochem. Geophys. Geosyst. 16, 563-578. doi: 10.1002/2014GC005631

Herzberg, C., and Gazel, E. (2009). Petrological evidence for secular cooling in mantle plumes. Nature 458, 619-622. doi: 10.1038/nature07857

Herzberg, C., and O'Hara, M. J. (2002). Plume-associated ultramafic magmas of Phanerozoic age. J. Petrol. 43, 1857-1883. doi: 10.1093/petrology/43.10.1857

Herzberg, C., Asimow, P. D., Arndt, N., Niu, Y., Lesher, C. M., and Fitton, J. G. (2007). Temperatures in ambient mantle and plumes: constraints from basalts, picrites, and komatiites. Geochem. Geophys. Geosyst. 8:Q02006. doi: 10.1029/2006GC001390

Hole, M. J. (2015). The generation of continental flood basalts by decompression melting of internally heated mantle. Geology 43, 311-314. doi: $10.1130 / \mathrm{G} 36442.1$

Hole, M. J., and Millet, J. M. (2016). Controls of mantle potential temperature and lithospheric thickness on magmatism in the North Atlantic igneous province. J. Petrol. 57, 417-436. doi: 10.1093/petrology/egw014

Hou, T., Zhang, Z., Encarnacion, J., and Santosh, M. (2012). Petrogenesis and metallogenesis of the Taihe gabbroic intrusion associated with Fe-Ti-oxide ores in the Panxi district, Emeishan large igneous province, southwest China. Ore Geol. Rev. 49, 109-127. doi: 10.1016/j.oregeorev.2012.09.004

Jerram, D. A., and Widdowson, M. (2005). The anatomy of Continental Flood Basalt Provinces: geological constraints on the processes and products of flood volcanism. Lithos 79, 385-405. doi: 10.1016/j.lithos.2004.09.009

Kamenetsky, V. S., Chung, S.-L., Kamenetsky, M. B., and Kuzmin, D. V. (2012). Picrites from the Emeishan large igneous province, SW China: a compositional continuum in primitive magmas and their respective mantle sources. J. Petrol. 53, 2095-2113. doi: 10.1093/petrology/egs045 
Kress, V. C., and Carmichael, I. S. E. (1991). The compressibility of silicate liquids containing $\mathrm{Fe}_{2} \mathrm{O}_{3}$ and the effect of composition, temperature, oxygen fugacity and pressure on their redox states. Contrib. Mineral. Petr. 108, 82-92. doi: $10.1007 / \mathrm{BF} 00307328$

Lai, S., Qin, J., Li, Y., Li, S., and Santosh, M. (2012). Permian high Ti/Y basalts from the eastern part of the Emeishan large igneous province, southwestern China: petrogenesis and tectonic implications. J. Asian Earth Sci. 47, 216-230. doi: 10.1016/j.jseaes.2011.07.010

Le Bas, M. J. (2000). IUGS reclassification of the high-Mg and picritic volcanic rocks. J. Petrol. 41, 1467-1470. doi: 10.1093/petrology/41.10.1467

Lee, C. T., Luffi, P., Höink, T., Li, J., Dasgupta, R., and Hernlund, J. (2010). Upsidedown differentiation and generation of a 'primordial' lower mantle. Nature 463, 930-933. doi: 10.1038/nature08824

Li, H., Zhang, Z., Ernst, R., Lü, L., Santosh, M., Zhang, D., et al. (2015). Giant radiating mafic dyke swarm of the Emeishan large igneous province: identifying the mantle plume centre. Terra Nova 27, 247-257. doi: 10.1111/ter.12154

Li, H., Zhang, Z., Santosh, M., Lü, L., Han, L., and Liu, W. (2017). Late Permian basalts in the Yanghe area, eastern Sichuan Province, SW China: implications for the geodynamics of the Emeishan flood basalt province and Permian global mass extinction. J. Asian Earth Sci. 134, 293-308. doi: 10.1016/j.jseaes.2016.11.029

Li, H., Zhang, Z., Santosh, M., Lü, L., Han, L., Liu, W., et al. (2016). Late Permian basalts in the northwestern margin of the Emeishan large igneous province: implications for the origin of the Sonpan-Ganzi terrane. Lithos 256-257, 75-87. doi: 10.1016/j.lithos.2016.03.021

Li, J., Xu, J.-F., Suzuki, K., He, B., Xu, Y.-G., and Ren, Z.-Y. (2010). Os, Nd and $\mathrm{Sr}$ isotope and trace element geochemistry of the Muli picrites: insights into the mantle source of the Emeishan large igneous province. Lithos 119, 108-122. doi: 10.1016/j.lithos.2010.06.002

Liu, J., Liu, F., He, J., Chen, H., and You, Q. (2001). Study of seismic tomography in Panxi paleorift area of southwestern China-structural features of crust and mantle and their evolution. Sci. China Ser. D 44, 277-288. doi: $10.1007 / B F 02882262$

Liu, X., Liang, Q., Li, Z., Castillo, P. R., Shi, Y., Xu, J., et al. (2017). Origin of Permian extremely high Ti/Y mafic lavas and dykes from western Guangxi, SW China: implications for the Emeishan mantle plume magmatism. J. Asian Earth Sci. 141, 97-111. doi: 10.1016/j.jseaes.2016.09.005

Mallmann, G., and O'Neill, H. St. C. (2009). Mantle melting as a function of oxygen fugacity compared with some other elements (Al, P, Ca, Sc, Ti, Cr, Fe, Ga, Y, Zr and Nb). J. Petrol. 50, 1765-1794. doi: 10.1093/petrology/egp053

Matthews, S., Shorttle, O., and Maclennan, J. (2016). The temperature of the Icelandic mantle from olivine-spinel aluminum exchange thermometry. Geochem. Geophys. Geosyst. 17, 4725-4752. doi: 10.1002/2016GC006497

Pang, K.-N., Zhou, M.-F., Qi, L., Shellnutt, J. G., Wang, C. Y., and Zhao, D. (2010). Flood basalt-related Fe-Ti oxide deposits in the Emeishan large igneous province, SW China. Lithos 119, 123-136. doi: 10.1016/j.lithos.2010. 06.003

Phipps Morgan, J., Reston, T. J., and Ranero, C. R. (2004). Contemporaneous mass extinctions, continental flood basalts, and 'impact signals': are mantle plumeinduced lithospheric gas explosions the casual link? Earth Planet. Sci. Lett. 217, 263-284. doi: 10.1016/S0012-821X(03)00602-2

Qi, L., and Zhou, M.-F. (2008). Platinum-group elemental and Sr-Nd-Os isotopic geochemistry of Permian Emeishan flood basalts in Guizhou Province, SW China. Chem. Geol. 148, 83-103. doi: 10.1016/j.chemgeo.2007.11.004

Rampino, M. R., and Caldeira, K. (2018). Comparison of the ages of the largebody impacts, flood-basalt eruptions, ocean-anoxic events and extinctions over the last 260 million years: a statistical study. Int. J. Earth Sci. 107, 601-606. doi: 10.1007/s00531-017-1513-6

Rampino, M. R., and Stothers, R. B. (1988). Flood basalt volcanism during the past 250 million years. Science 241, 663-668. doi: 10.1126/science.241.4866.663

Ren, Z.-Y., Wu, Y.-D., Zhang, L., Nichols, A. R. L., Hong, L.-B., Zhang, Y.H., et al. (2017). Primary magmas and mantle sources of Emeishan basalts constrained from major element, trace element and $\mathrm{Pb}$ isotope compositions of olivine-hosted melt inclusions. Geochim. Cosmochim Acta 208, 63-85. doi: 10.1016/j.gca.2017.01.054

Rey, P. (2015). The geodynamics of mantle melting. Geology 43, 367-368. doi: $10.1130 /$ focus 042015.1
Richards, M., Duncan, R. A., and Courtillot, V. E. (1989). Flood basalts and hotspot tracks: plumes heads and tails. Science 246, 103-107. doi: $10.1126 /$ science. 246.4926 .103

Rooney, T. O., Herzberg, C., and Bastow, I. D. (2012). Elevated mantle temperature beneath East Africa. Geology 40, 27-30. doi: 10.1130/G32382.1

Self, S., Thordarson, T., and Widdowson, M. (2005). Gas fluxes from flood basalt eruptions. Elements 1, 283-287. doi: 10.2113/gselements.1.5.283

Shellnutt, J. G. (2014). The Emeishan large igneous province: a synthesis. Geosci. Front. 5, 369-394. doi: 10.1016/j.gsf.2013.07.003

Shellnutt, J. G., and Hsieh, R. B.-J. (2016). Mantle potential temperature estimates of basalt from the East Taiwan Ophiolite. Terr. Atmos. Ocean. Sci. 27, 853-863. doi: 10.3319/TAO.2016.05.24.01(TT)

Shellnutt, J. G., and Iizuka, Y. (2012). Oxidation zonation within the Emeishan large igneous province: evidence from mantle-derived syenitic plutons. J. Asian Earth Sci. 54-55, 31-40. doi: 10.1016/j.jseaes.2012.03.011

Shellnutt, J. G., and Jahn, B.-M. (2010). Formation of the Late Permian Panzhihua plutonic-hypabyssal-volcanic igneous complex: implications for the genesis of Fe-Ti oxide deposits and A-type granites of SW China. Earth Planet. Sci. Lett. 289, 509-519. doi: 10.1016/j.epsl.2009.11.044

Shellnutt, J. G., and Jahn, B.-M. (2011). Origin of Late Permian Emeishan basaltic rocks from the Panxi region (SW China): implications for the Ti-classification and spatial-compositional distribution of the Emeishan basalts. J. Volcanol. Geoth. Res. 199, 85-95. doi: 10.1016/j.jvolgeores.2010.10.009

Shellnutt, J. G., and Wang, K.-L. (2014). An ultramafic primary magma for a low Si, high Ti-Fe gabbro in the Panxi region of the Emeishan large igneous province, SW China. J. Asian Earth Sci. 79, 329-344. doi: 10.1016/j.jseaes.2013.10.017

Shellnutt, J. G., and Zhou, M.-F. (2007). Permian peralkaline, peraluminous and metaluminous A-type granites in the Panxi district, SW China: their relationship to the Emeishan mantle plume. Chem. Geol. 243, 286-316. doi: 10.1016/j.chemgeo.2007.05.022

Shellnutt, J. G., Denyszyn, S., and Mundil, R. (2012). Precise age determination of mafic and felsic intrusive rocks from the Permian Emeishan large igneous province (SW China). Gondwana Res. 22, 118-126. doi: 10.1016/j.gr.2011.10.009

Shellnutt, J. G., Dostal, J., and Yeh, M.-W. (2018). Mantle source heterogeneity of the Early Jurassic basalt of eastern North America. Int. J. Earth Sci. 107, 1033-1058. doi: 10.1007/s00531-017-1519-0

Shellnutt, J. G., Zhou, M.-F., Yan, D.-P., and Wang, Y. (2008). Longevity of the Permian Emeishan mantle plume (SW China): 1 million years; 8 million years or 18 million years? Geol. Mag. 145, 373-388. doi: 10.1017/S0016756808004524

Sheth, H. C. (1999). Flood basalts and large igneous province from deep mantle plumes: fact, fiction, and fallacy. Tectonophysics 311, 1-29. doi: 10.1016/S0040-1951(99)00150-X

Sobolev, S. V., Sobolev, A. V., Kuzmin, D. V., Krivolutskaya, N. A., Petrunin, A. G., Arndt, N. T., et al. (2011). Linking mantle plumes, large igneous provinces and environmental catastrophes. Nature 477, 312-316. doi: 10.1038/nature10385

Song, X.-Y., Zhou, M.-F., Hou, Z.-Q., Xao, Z.-M., Wang, Y.-L., and Li, Y. (2001). Geochemical constraints on the mantle source of the upper Permian Emeishan continental flood basalts, southwest China. Int. Geol. Rev. 43, 213-225. doi: 10.1080/00206810109465009

Song, X.-Y., Zhou, M.-F., Keays, R. R., Cao, Z.-M., Sun, M., and Qi, L. (2006). Geochemistry of the Emeishan flood basalts at Yangliuping, Sichuan, SW China: implications for sulfide segregation. Contrib. Mineral. Petr. 152, 53-74. doi: 10.1007/s00410-006-0094-3

Sun, Y., Lai, X., Wignall, P. B., Widdowson, M., Ali, J. R., Jiang, H., et al. (2010). Dating the onset and nature of the middle Permian Emeishan large igneous province eruptions in SW China using conodont biostratigraphy and its bearing on mantle plume uplift models. Lithos 119, 20-33. doi: $10.1016 /$ j.lithos.2010.05.012

Tao, Y., Putirka, K., Hu, R.-Z., and Li, C. (2015). The magma plumbing system of the Emeishan large igneous province and its role in basalt magma differentiation in a continental setting. Am. Mineral. 100, 2509-2517. doi: 10.2138/am-2015-4907

Tran, H. T., Lan, C.-Y., Usuki, T., Shellnutt, J. G., Pham, T. D., Tran, T. A., et al. (2015). Petrogenesis of Late Permian silicic rocks of Tu Le basin and Phan Si Pan uplift (NW Vietnam) and their association with the Emeishan large igneous province. J. Asian Earth Sci. 109, 1-19. doi: 10.1016/j.jseaes.2015.05.009 
Ukstins Peate, I., and Bryan, S. E. (2008). Re-evaluating plume induced uplift in the Emeishan large igneous province. Nat. Geosci. 1, 625-629. doi: $10.1038 /$ ngeo 281

Ukstins Peate, I., and Bryan, S. E. (2009). Reply to Pre-eruptive uplift in the Emeishan. Nat. Geosci. 2, 531-532. doi: 10.1038/ngeo600

Usuki, T., Lan, C.-Y., Tran, T. H., Pham, T. D., Wang, K.-L., Shellnutt, J. G., et al. (2015). Zircon U-Pb ages and Hf isotopic compositions of alkaline silicic magmatic rocks in the Phan Si Pan-Tu Le region, northern Vietnam: identification of a displaced western extension of the Emeishan large igneous province. J. Asian Earth Sci. 97, 102-124. doi: 10.1016/j.jseaes.2014.10.016

Wang, C. Y., Zhou, M.-F., and Qi, L. (2007). Permian flood basalts and mafic intrusions in the Jinping (SW China)-Song Da (northern Vietnam) district: mantle source, crustal contamination and sulfide segregation. Chem. Geol.243, 317-343. doi: 10.1016/j.chemgeo.2007.05.017

Wang, Y., Luo, Z., We, P., Chen, L., and Hao, J. (2014). A new interpretation of the sedimentary environment before and during eruption of the Emeishan LIP southwest China. Int. Geol. Rev. 56, 1295-1313. doi: 10.1080/00206814.2014.936056

Weislogel, A. L., Graham, S. A., Chang, E. Z., Wooden, J. L., and Gehrels, G. E. (2010). Detrital zircon provenance from three turbidite depocenters of the Middle-Upper Triassic Songpan-Ganzi complex, central China: record of collisional tectonics, erosional exhumation, and sediment production. Geol. Soc. Am. Bull. 122, 2041-2062. doi: 10.1130/B26606.1

Whalen, L., Gazel, E., Vidito, C., Puffer, J., Bizimis, M., Henika, W., et al. (2015). Supercontinental inheritance and its influence on supercontinental breakup: the central Atlantic magmatic province and the breakup of Pangea. Geochem. Geophys. Geosyst. 16, 3532-3554. doi: 10.1002/2015GC005885

White, R. S., and McKenzie, D. (1989). Magmatism at rift zones: the generation of volcanic continental margins and flood basalts. J. Geophys. Res. 94, 7685-7729. doi: 10.1029/JB094iB06p07685

White, R. S., and McKenzie, D. (1995). Mantle plumes and flood basalts. J. Geophys. Res. 100, 543-585. doi: 10.1029/95JB01585

Wignall, P. (2001). Large igneous provinces and mass extinctions. Earth Sci. Rev. 53, 1-33. doi: 10.1016/S0012-8252(00)00037-4

Xiao, L., Xu, Y. G., Mei, H. J., Zheng, Y. F., He, B., and Pirajno, F. (2004). Distinct mantle sources of low-Ti and high-Ti basalts from the western Emeishan large igneous province, SW China: implications for plume-lithosphere interaction. Earth Planet. Sci. Lett. 228, 525-546. doi: 10.1016/j.epsl.2004.10.002

$\mathrm{Xu}, \mathrm{R}$., and Liu, Y. (2016). Al-in-olivine thermometry evidence for the mantle plume origin of the Emeishan large igneous province. Lithos 266-267, 362-366. doi: 10.1016/j.lithos.2016.10.016

Xu, Y. G., He, B., Chung, S. L., Menzies, M., and Frey, F. A. (2004). Geologic, geochemical, and geophysical consequences of plume involvement in the Emeishan flood-basalt province. Geology 32, 917-920. doi: 10.1130/G2 0602.1
Xu, Y., Chung, S. L., Jahn, B.-M., and Wu, G. (2001). Petrologic and geochemical constraints on the petrogenesis of Permian-Triassic Emeishan flood basalts in southwestern China. Lithos 58, 145-168. doi: 10.1016/S0024-4937(01)00055-X

Xu, Y.-G., Chung, S.-L., Shao, H., and He, B. (2010). Silicic magmas form the Emeishan large igneous province, southwest China: petrogenesis and their link with the end-Guadalupian biological crisis. Lithos 119, 47-60. doi: 10.1016/j.lithos.2010.04.013

Yeh, M.-W., and Shellnutt, J. G. (2016). The initial break-up of Pangaea elicited by Late Palaeozoic deglaciation. Sci. Rep. 6:31442. doi: 10.1038/srep31442

Zhang, X.-Q., Song, X.-Y., Chen, L.-M., Xie, W., Yu, S.-Y., Zheng, W.-Q., et al. (2012). Fractional crystallization and the formation of the thick Fe-Ti-V oxide layers in the Baima layered intrusion, SW China. Ore Geol. Rev. 49, 96-108. doi: 10.1016/j.oregeorev.2012.09.003

Zhang, Z., Mahoney, J. J., Mao, J., and Wang, F. (2006). Geochemistry of picritic and associated basalt flows of the western Emeishan flood basalt province, China. J. Petrol. 47, 1997-2019. doi: 10.1093/petrology/egl034

Zheng, L., Yang, Z., Tong, Y., and Yuan, W. (2010). Magnetostratigraphic constraints on two-stage eruptions of the Emeishan continental flood basalts. Geochem. Geophys. Geosyst. 11:Q12014. doi: 10.1029/2010GC003267

Zhong, Y.-T., He, B., Mundil, R., and Xu, Y.-G. (2014). CA-TIMS zircon U-Pb dating of felsic ignimbrite from the Binchuan section: implications for the termination age of the Emeishan large igneous province. Lithos 204, 14-19. doi: 10.1016/j.lithos.2014.03.005

Zhou, M.-F., Arndt, N. T., Malpas, J., Wang, C. Y., and Kennedy, A. K. (2008). Two magma series and associated ore deposit types in the Permian Emeishan large igneous province, SW China. Lithos 103, 352-368. doi: 10.1016/j.lithos.2007.10.006

Zi, J., Fan, W., Wang, Y., Peng, T., and Guo, F. (2008). Geochemistry and petrogenesis of the Permian mafic dykes in the Panxi region, SW China. Gondwana Res. 14, 368-382. doi: 10.1016/j.gr.2008.02.008

Zi, J., Fan, W.-M., Wang, Y.-J., Cawood, P. A., Peng, T.-P., Sun, L.-H., et al. (2010). $\mathrm{U}-\mathrm{Pb}$ geochronology and geochemistry of the Dashibao basalt in the SongpanGanzi terrane, SW China, with implications for the age of the Emeishan volcanism. Am. J. Sci. 310, 1054-1080. doi: 10.2475/09.2010.11

Conflict of Interest Statement: The authors declare that the research was conducted in the absence of any commercial or financial relationships that could be construed as a potential conflict of interest.

Copyright (๑) 2018 Shellnutt and Pham. This is an open-access article distributed under the terms of the Creative Commons Attribution License (CC BY). The use, distribution or reproduction in other forums is permitted, provided the original author(s) and the copyright owner are credited and that the original publication in this journal is cited, in accordance with accepted academic practice. No use, distribution or reproduction is permitted which does not comply with these terms. 